\title{
ACCUMULATION AND PARTITION OF DRY MASS AND NITROGEN IN THREE MAIZE (Zea mays L.) HYBRIDS GROWN UNDER FIVE PLANTING DENSITIES
}

\author{
LIU, J. ${ }^{1,2}-$ YUAN, J. ${ }^{2}-$ CAI, H. ${ }^{2}-$ REN J. $^{2}-$ LIANG, Y. ${ }^{2}-$ HOU, W. ${ }^{1 *}-$ CHEN, G. $^{1 *}$ \\ ${ }^{I}$ College of Resources and Environmental Sciences, Jilin Agricultural University \\ Changchun 130118, China \\ ${ }^{2}$ Institute of Agricultural Resource and Environment, Jilin Academy of Agricultural Sciences, \\ Key Laboratory of Plant Nutrition and Agro-Environment in Northeast Region MOA, \\ Changchun 130033, China \\ ${ }^{*}$ Corresponding author \\ e-mail:wenfenghou@163.com \\ (Received 19 $9^{\text {th }}$ Jan 2020; accepted $2^{\text {nd }}$ Jul 2020)
}

\begin{abstract}
Following the development of hybrid maize (Zea mays L.) breeding technologies and advanced agricultural strategies, we postulated that maize grain yield and nitrogen $(\mathrm{N})$ uptake and utilization could be further improved by selecting appropriate hybrids and identifying optimum planting densities. Five field experiments were conducted in 2013, 2014 and 2015 in Jilin Province, China. Our orthogonal design demonstrated significant interactive effects of maize hybrid and planting density on grain yield. The optimum planting densities, i.e., those associated with the best grain yields for hybrids ZD958, XY335 and LM33, were 74.0-81.4, 74.3-79.1, and 78.6-89.7 $\times 10^{3} \mathrm{ha}^{-1}$, respectively, across 3 years and two sites. Increased planting density had a significant inhibitory effect on the leaf growth and development of individual plants, but this was offset by positive effects at the population level: increased planting density significantly increased the population leaf area index. Increased planting density improved dry mass and total aboveground $\mathrm{N}$ uptake (TNU), and promoted dry mass and $\mathrm{N}$ remobilization in stalks and leaves.
\end{abstract}

Keywords: leaf area index, interaction effects, remobilization rate, nitrogen uptake, nitrogen utilization

\section{Introduction}

Maize (Zea mays L.), rice (Oryza sativa L.) and wheat (Triticum aestivum L.) are the three main staple grain crops grown in China (Ma et al., 2009). Maize accounted for $43.6 \%$ of the total planted area and $42.8 \%$ of the total grain yield across these three crops in 2018 (National Bureau of Statistics, 2018). The Northeast China Plain is the major maize growing area in the country. Maize grown in Heilongjiang, Jilin and Liaoning Provinces constituted $31.5 \%$ of the total planted area and accounted for $32.8 \%$ of the grain yield (National Bureau of Statistics, 2018). Maize is an important component of the human diet, and is also used for animal feed, forage, biomass fuel, etc. (Diós et al., 2009; Chen et al., 2011; Grassini and Cassman, 2012). The grain yield of maize in the last two decades was $25 \%$ higher than over the previous 50 years; the increase has resulted from developments in breeding technology and agricultural practices (Duvick, 2005; Ciampitti and Vyn, 2012). Chen et al. (2013a) also reported that developments in breeding technology in the past 40 years have significantly increased maize yield. Half of the dry mass of a maize plant at maturity is formed after the silking stage (Tollenaar et al., 2004; Lee and Tollenaar, 2007). Chen et al. (2014) reported that almost all the grain yield at maturity is attributable to photosynthetic production after the silking stage. Leaves are the major photosynthetic organs for dry mass production in maize. Among other variables, genetic hybrids selection and plant $\mathrm{N}$ 
availability are important factors influencing maize grain yield (Chen et al., 2015). With the development of modern breeding technology, new maize hybrids usually have extended periods of photosynthetic production, larger leaf area indices, delayed leaf senescence and elevated dry mass production rates (Borrell et al., 2001; Duvick, 2005; Echarte et al., 2008). The remobilization of vegetative $\mathrm{N}$ and $\mathrm{N}$ uptake after the silking stage also contributes to grain $\mathrm{N}$ accumulation. However, it is difficult to achieve a balance between the remobilization of vegetative $\mathrm{N}$ and $\mathrm{N}$ uptake after the silking stage, because increased leaf $\mathrm{N}$ remobilization decreases dry mass production after the silking stage. The choice of maize hybrids significantly affects the immobilization of leaf $\mathrm{N}$, and $\mathrm{N}$ uptake, after the silking stage (Coque and Gallais, 2007; Ciampitti and Vyn, 2012). Modern breeding technology has produced the widely cultivated leaf-stay-green hybrids, which are generally grown under high $\mathrm{N}$ inputs on fertile soils (Bertin and Gallais, 2000). Compared to older hybrids, modern stay-green hybrids typically have higher $\mathrm{N}$ uptake after the silking stage, and a lower $\mathrm{N}$ remobilization rate (He et al., 2004; Pommel et al., 2006; Ciampitti and Vyn, 2012).

Yield is strongly related to hybrids, but changes in other agricultural factors, such as planting density, also affect yield responses. The production of biomass depends on photosynthesis at the whole plant level rather at the single leaf level. Therefore, increasing photosynthesis through increasing planting density may be an effective means to further increase maize biomass and grain yield. Maize planting density in China varies among agricultural zones, and according to the cultivation habits of farmers, etc. Planting density ranges from $49,850 \mathrm{ha}^{-1}$ to $65,180 \mathrm{ha}^{-1}$ on the Huaihai Plain, in northwestern China; both of those values are much lower than those in the USA (Meng et al., 2013; Li et al., 2016). Increases in planting density necessarily intensify competition. The effects of planting density on grain yield, the leaf area of individual plants, the population leaf area index (LAI), leaf photosynthesis, and other variables have been examined in previous works (Amanullah et al., 2007; Liu et al., 2015; Xue et al., 2015). Li et al. (2015) found that the elevated grain yield of modern maize hybrids is largely a result of enhanced stay-green characteristics and increased photosynthetic capacity after anthesis. Higher planting density leads to undesirably high leaf area indices that cause self-shading, which may reduce yield (Liu et al., 2015; Srinivasan et al., 2017). Hence, determining the effects of hybrid and planting density on leaf development will be of great significance in the management of maize cultivation.

Hybrid Xianyu335 (XY335) has elevated dry mass accumulation at silking and higher $\mathrm{N}$ recovery efficiency than that of Zhengdan958 (ZD958) (Chen et al., 2014). However, the differences between these two hybrids in $\mathrm{N}$ remobilization and $\mathrm{N}$ uptake after silking remain unclear. In the current study, we designed a 3-year program to develop a better understanding of the possible interaction between hybrid and planting density. We analyzed the response of grain yield, total aboveground $\mathrm{N}$ uptake (TNU), $\mathrm{N}$ partial factor productivity (NPFP), total $\mathrm{N}$ in the grain as a fraction of TNU (nitrogen harvest index; NHI), dry mass and $\mathrm{N}$ accumulation rates at silking and maturity, and stalk and leaf remobilization rates of dry mass and $\mathrm{N}$ in three widely used hybrids grown on the Northeast Plain of China. The aim of this study was to explore physiological mechanisms to achieve higher grain yield and $\mathrm{N}$ utilization efficiency by combined testing of (i) maize hybrids and (ii) planting densities. 


\section{Materials and methods}

\section{Experimental site}

Five field experiments were conducted at Halahai $\left(44^{\circ} 32^{\prime} 50^{\prime \prime} \mathrm{N}, 125^{\circ} 09^{\prime} 56^{\prime \prime} \mathrm{E}\right)$ in 2013, 2014 and 2015, and at Gongzhuling $\left(43^{\circ} 29^{\prime} 55^{\prime \prime} \mathrm{N}, 124^{\circ} 48^{\prime} 43^{\prime \prime} \mathrm{E}\right)$ in 2014 and 2015. Both sites are situated in Jilin Province, which is a typical spring maize growing region in Northeast China. The respective soil physical and chemical characteristics in Halahai and Gongzhuling at the beginning of the experiments were as follows: organic matter, 25.0 and $21.0 \mathrm{~g} \mathrm{~kg}^{-1}$; available $\mathrm{N}, 121.0$ and $111.8 \mathrm{mg} \mathrm{kg} \mathrm{k}^{-1}$; available phosphorus (P), 24.2 and $31.5 \mathrm{mg} \mathrm{kg}^{-1}$; potassium (K), 166.9 and $185.9 \mathrm{mg} \mathrm{kg}^{-1}$; and $\mathrm{pH}, 7.89$ and 6.00 (under a water/soil mixture ratio of 2.5:1).

The precipitation data during the maize growth stage are presented in Fig. 1, which shows major precipitation in Gongzhuling in 2015, especially during the seedling stage. The growth degree units in 2013, 2014 and 2015 of Halahai were 3,055, 2,900 and $2,974{ }^{\circ} \mathrm{C}$ respectively, and that in 2013 and 2014 of Gongzhuling were 3,186 and $3,200{ }^{\circ} \mathrm{C}$ respectively.

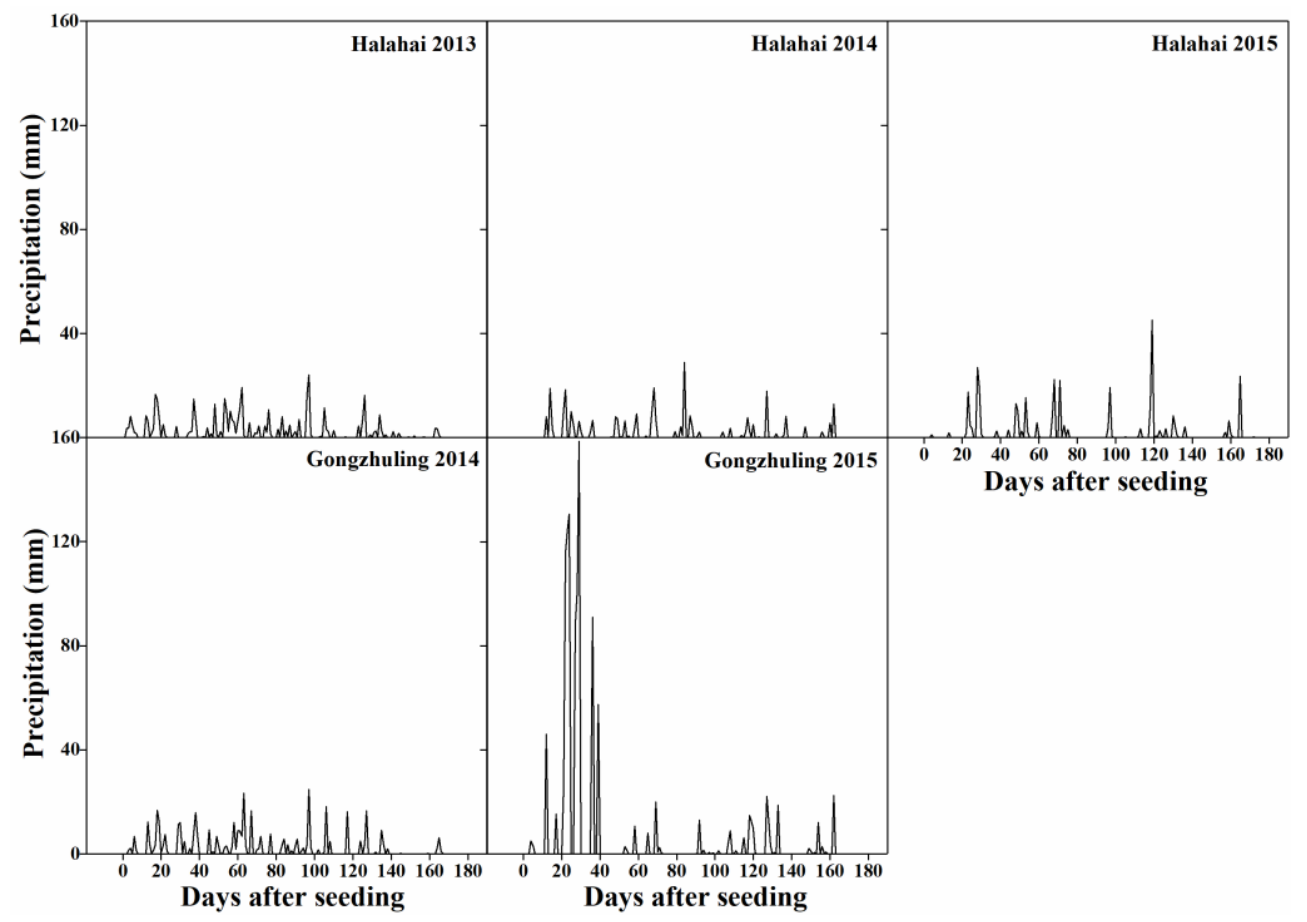

Figure 1. Precipitation at two study sites during the maize growth stage

\section{Plant materials}

Three maize hybrids, ZD958, XY335 and LM33, were included in the study; these are the dominant hybrids used on the Northeast China Plain (Chen et al., 2013b; Gu et al., 2017). ZD958 was developed by the Henan Academy of Agricultural Science, Henan Province, China; XY335 was developed by the Pioneer Technology Company, Tieling, Jilin Province, China; LM33 was developed by the Limin Seed Company, Songyuan, Jilin Province China. The main agronomic properties of the three maize hybrids were shown in Table 1. 
Table 1. The main agronomic properties of the three maize hybrids

\begin{tabular}{c|c|c|c|c|c|c}
\hline Hybrids & $\begin{array}{c}\text { Authorized } \\
\text { No. }\end{array}$ & $\begin{array}{c}\text { Growing } \\
\text { degree units } \\
\left(\mathbf{1 \mathbf { 1 0 } ^ { \circ } \mathbf { C } )}\right.\end{array}$ & $\begin{array}{c}\text { Growing } \\
\text { period } \\
(\mathbf{d a y s})\end{array}$ & $\begin{array}{c}\text { Plant height } \\
(\mathbf{c m})\end{array}$ & $\begin{array}{c}\text { Ear length } \\
(\mathbf{c m})\end{array}$ & $\begin{array}{c}\mathbf{1 0 0} \text { grain } \\
\text { weight } \\
(\mathbf{g})\end{array}$ \\
\hline ZD958 & GSY20000009 & 2550 & 128 & 240 & 20.0 & 33.0 \\
XY335 & GSY2004017 & 2650 & 120 & 286 & 18.5 & 39.3 \\
LM33 & JSY2013030 & 2730 & 128 & 270 & 20.0 & 36.5 \\
\hline
\end{tabular}

\section{Experimental design}

A split-plot block design with three replications was used in the five field experiments. Three hybrids were set as the main plot factors, and five planting densities (D1, D2, D3, D4 and D5: 45,000, 60,000, 75,000, 90,000 and 105,000 ha $\mathrm{ha}^{-1}$, respectively) were set as sub-plot factors. All plots were $7 \mathrm{~m}$ long, and comprised eight rows spaced $0.65 \mathrm{~m}$ apart. Plots were fertilized with $225 \mathrm{~kg} \mathrm{~N} \mathrm{ha}^{-1}, 90 \mathrm{~kg} \mathrm{P}_{2} \mathrm{O}_{5} \mathrm{ha}^{-1}$ and $90 \mathrm{~kg} \mathrm{~K} 2 \mathrm{O}$ ha $^{-1}$. All $\mathrm{P}_{2} \mathrm{O}_{5}$ and $\mathrm{K}_{2} \mathrm{O}$ amendments were applied as base fertilizer. We applied $40 \%$ of $\mathrm{N}$ in the base fertilizer, and $40 \%$ and $20 \%$ at the jointing and silking stages, respectively.

\section{Crop cultivation}

Maize seeds were sown on May 3, 2013, April 29, 2014 and April 30, 2015 in Halahai, and on April 26, 2014 and April 25, 2015 in Gongzhuling with semiautomatic planters (Fig. 2). Maize plants were harvested on September 27, 2013, September 25, 2014 and September 27, 2015 in Halahai, and on September 26, 2014 and September 27, 2015 in Gongzhuling. All of the agricultural practices used followed the recommendations of local agricultural technology departments.

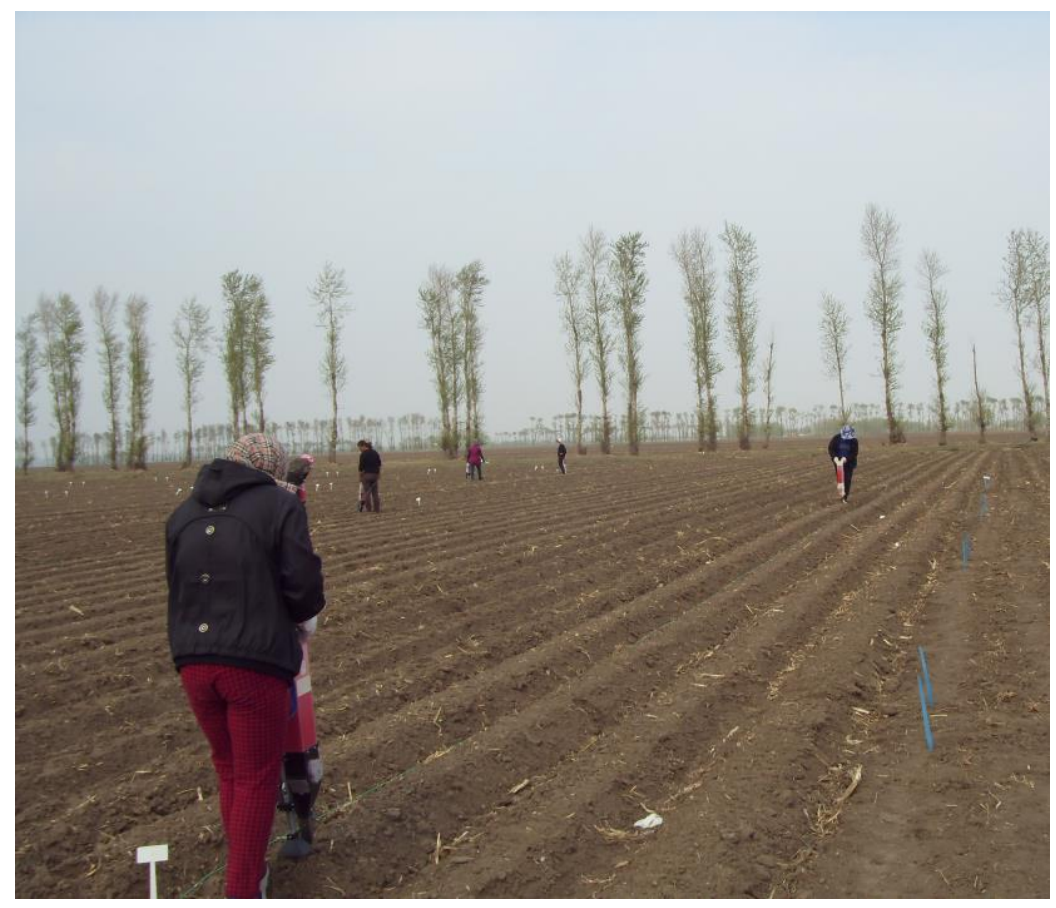

Figure 2. Maize seeding of different planting densities with semiautomatic planters 


\section{Measurements}

Three representative plants from each plot were sampled at silking and maturity. All samples were separated into leaves, stalks and grain. The green leaf area of each plant at the silking stage was calculated (after separating component organs) using the following formula: length $\times$ leaf width $\times 0.75$ (Gallais et al., 2006). Leaf area index (LAI) was the total leaf area of per unit land area. All samples were oven-dried at $105{ }^{\circ} \mathrm{C}$ for 30 minutes and then dried at $70{ }^{\circ} \mathrm{C}$ to a constant mass for dry weights measurements. After measuring the dry weights of different samples, they were ground to powder and passed through a $0.25-\mathrm{mm}$ sieve. We then weighed out $0.1 \mathrm{~g}$ of powder from each sample and digested it in $\mathrm{H}_{2} \mathrm{SO}_{4}$ and $\mathrm{H}_{2} \mathrm{O}_{2}$ (Wolf, 1982). The $\mathrm{N}$ concentration in the solution was determined with a continuous flow analyzer (AA3; Seal Analytical Inc., Southampton, UK). Grain yield at maturity was determined from 20 plants and adjusted to a $14 \%$ moisture content.

\section{Calculations}

Stalk and leaf weight remobilization efficiency, the contributions to grain yield of stalk and leaf mass remobilization, stalk and leaf $\mathrm{N}$ remobilization efficiencies and the contributions to grain yield of stalk and leaf $\mathrm{N}$ remobilization were calculated as follows (Chen et al., 2014):

Stalk mass remobilization efficiency $(\%)=($ stalk mass at silking stalk mass at maturity) / stalk mass at silking $\times 100$

Leaf mass remobilization efficiency $(\%)=($ leaf mass at silking - leaf mass at maturity) / leaf mass at silking $\times 100$

Contribution to grain yield by stalk mass remobilization $(\%)=($ stalk mass at silking - stalk mass at maturity) / grain yield at maturity $\times 100$

Contribution to grain yield by leaf mass remobilization $(\%)=($ leaf mass at silking - leaf mass at maturity) / grain yield at maturity $\times 100$

Stalk $\mathrm{N}$ remobilization efficiency $(\%)=($ stalk $\mathrm{N}$ uptake at silking stalk $\mathrm{N}$ uptake at maturity) / stalk $\mathrm{N}$ uptake at silking $\times 100$

Leaf $\mathrm{N}$ remobilization efficiency $(\%)=($ leaf $\mathrm{N}$ uptake at silking - leaf $\mathrm{N}$ uptake at maturity) / leaf $\mathrm{N}$ uptake at silking $\times 100$

Contribution to grain $\mathrm{N}$ by stalk $\mathrm{N}$ remobilization $=($ stalk $\mathrm{N}$ uptake at silking - stalk $\mathrm{N}$ uptake at maturity) / grain $\mathrm{N}$ uptake at maturity $\times 100$

Contribution to grain $\mathrm{N}$ by leaf $\mathrm{N}$ remobilization $(\%)=$ (leaf $\mathrm{N}$ uptake at silking - leaf $\mathrm{N}$ uptake at maturity) / grain $\mathrm{N}$ uptake at maturity $\times 100$

The N uptake NHI was calculated as follows (Chen et al., 2014; Hou et al., 2019): 
$\mathrm{N}$ uptake by grain $\left(\mathrm{GN}, \mathrm{kg} \mathrm{kg}^{-1}\right)=\mathrm{N}$ content of grain $\times$ grain mass

$\mathrm{N}$ uptake by straw $\left(\mathrm{SN}, \mathrm{kg} \mathrm{kg}^{-1}\right)=\mathrm{N}$ content of straw $\times$ straw mass

$\mathrm{N}$ uptake by leaf $\left(\mathrm{LN}, \mathrm{kg} \mathrm{kg}^{-1}\right)=\mathrm{N}$ content of leaf $\times$ leaf mass

Total $\mathrm{N}$ uptake $(\mathrm{TNU})\left(\mathrm{kg} \mathrm{kg}^{-1}\right)=\mathrm{GN}+\mathrm{SN}+\mathrm{LN}$

$\mathrm{N}$ harvest index $(\mathrm{NHI})=\mathrm{GN} /(\mathrm{GN}+\mathrm{SN}+\mathrm{LN})$

The partial factor productivity of applied N (NPFP) was calculated as follows (Sun et al., 2018):

$$
\operatorname{NPFP}\left(\mathrm{kg} \mathrm{kg}^{-1}\right)=\text { grain yield } / \mathrm{N} \text { rate }
$$

\section{Data analysis}

All data were analyzed using ANOVA. Significant pairwise differences between means were identified by least significant difference (LSD) tests at the 0.05 and 0.01 levels of significance. The ANOVA that demonstrated significant effects of maize hybrid, plant density, year, site, and their interactions was executed with SPSS 17.0 software (SPSS Inc., Chicago, IL, USA). The figures were generated with Origin Pro 8.0 software (OriginLab Corp. Northampton. MA, USA).

\section{Results}

\section{Grain yield}

The effects of time, hybrid, site and planting density on grain yield are shown in Fig. 3. Among the experimental years, the grain yield was similar between 2013 and 2014, and both were significantly higher than that in 2015. The grain yield in 2015 was $17.3 \%$ lower on average than during the previous 2 years. The reduced grain yield in 2015 may have been a consequence of high precipitation in Gongzhuling during the seedling stage (Fig. 1). Among the three hybrids, XY335 had a higher grain yield that was $7.5 \%$ higher on average than Zhengdan958 (ZD958) and Limin33 (LM33). The environment also had significant effects on grain yield. The grain yield in Halahai was $12.5 \%$ higher than that in Gongzhuling. Planting density, an important agronomic measure, had a significant effect on grain yield. Grain yield increased at first, and then decreased, with increasing planting density. Density treatment D3 had the highest grain yield (Fig. 3).

The relationship between planting density and grain yield was described using regression equations (Table 2). The regression equations showed that grain yield did not always increase with planting density. In the field trials, the most appropriate planting density varied by hybrid, year and experimental site. Among the hybrids, LM33 had the highest appropriate planting density. The regression equations also showed that the lower average grain yield in 2015 was due to the lower grain yield in Gongzhuling. 

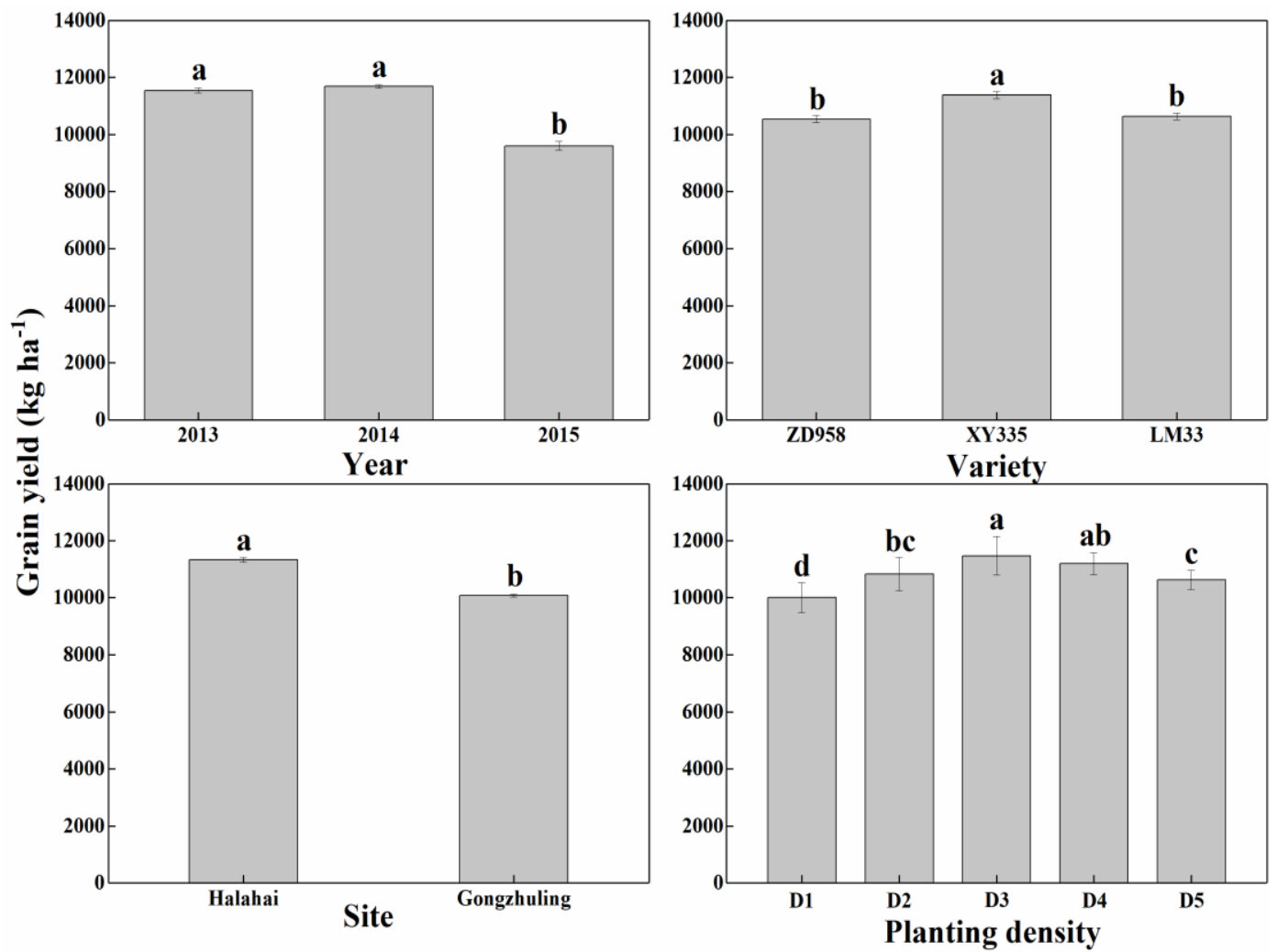

Figure 3. Grain yields of maize by year, site, hybrids, and planting density. Values are means \pm SE. Different lower case letters within panels identify significant pairwise differences between means (least significant difference [LSD] test; P < 0.05). D1, D2, D3, D4 and D5 correspond to planting densities of 45,000,60,000, 75,000, 90,000 and 105,000 ha $\mathrm{h}^{-1}$, respectively

Table 2. Regression equations describing the relationship between planting density and yield

\begin{tabular}{|c|c|c|c|c|c|c|}
\hline Year & Site & Hybrid & Regression equation & $\mathbf{R}^{2}$ & $\begin{array}{c}\text { Predicted } \\
\text { extremum }\end{array}$ & $\mathbf{X}$ \\
\hline \multirow{3}{*}{2013} & \multirow{3}{*}{ Halahai } & ZD958 & $Y=-0.8717 X^{2}+138.99 X+4754$ & 0.9805 & 10265 & 74.0 \\
\hline & & XY335 & $\mathrm{Y}=-0.87 \mathrm{X}^{2}+136.45 \mathrm{X}+5477$ & 0.9023 & 10827 & 78.4 \\
\hline & & LM33 & $Y=-0.7019 X^{2}+118.92 X+4810$ & 0.8568 & 9847 & 84.7 \\
\hline \multirow{6}{*}{2014} & \multirow{3}{*}{ Halahai } & ZD958 & $Y=-0.8978 X^{2}+142.94 X+4286$ & 0.8879 & 9975 & 79.6 \\
\hline & & XY335 & $Y=-1.7201 X^{2}+264.87 X+920$ & 0.9201 & 11116 & 77.0 \\
\hline & & LM33 & $Y=-0.7599 X^{2}+136.33 X+4422$ & 0.9586 & 10536 & 89.7 \\
\hline & \multirow{3}{*}{ Gongzhuling } & ZD958 & $Y=-1.1598 X^{2}+181.57 X+3267$ & 0.9397 & 10373 & 78.3 \\
\hline & & XY335 & $Y=-1.1571 X^{2}+182.99 X+3726$ & 0.8868 & 10960 & 79.1 \\
\hline & & LM33 & $Y=-1.1241 X^{2}+188.82 X+2791$ & 0.9802 & 10721 & 84.0 \\
\hline \multirow{6}{*}{2015} & \multirow{3}{*}{ Halahai } & ZD958 & $Y=-1.2442 X^{2}+194.17 X+1888$ & 0.9501 & 9465 & 78.0 \\
\hline & & XY335 & $Y=-1.4991 X^{2}+228.72 X+1901$ & 0.8477 & 10625 & 76.3 \\
\hline & & LM33 & $Y=-1.0473 X^{2}+164.72 X+3133$ & 0.8744 & 9610 & 78.6 \\
\hline & \multirow{3}{*}{ Gongzhuling } & ZD958 & $Y=-0.7671 X^{2}+124.83 X+2443$ & 0.8966 & 7521 & 81.4 \\
\hline & & XY335 & $Y=-0.7349 X^{2}+109.27 X+4079$ & 0.9480 & 8141 & 74.3 \\
\hline & & LM33 & $Y=-0.5895 X^{2}+98.395 X+2813$ & 0.9665 & 6918 & 83.5 \\
\hline
\end{tabular}

"Predicted extremum" indicates the highest grain yield $\left(\mathrm{kg} \mathrm{ha}^{-1}\right)$ obtained from the regression equation. $\mathrm{X}$ refers to a suitable planting density $\left(10^{3}\right.$ plants $\left.\mathrm{ha}^{-1}\right)$ at the predicted extremum obtained from the regression equations 


\section{Leaf development}

The leaf areas of plants at the silking stage are shown in Fig. 4, values were highest in 2014 and lowest in 2015. Leaf area varied significantly by hybrid in the following order: ZD958 > XY335 > LM33. Leaf area did not vary significantly between the two experimental sites. Increased planting density significantly decreased leaf area. The leaf area in treatment D5 was $26.9 \%$ smaller than that in treatment D1.

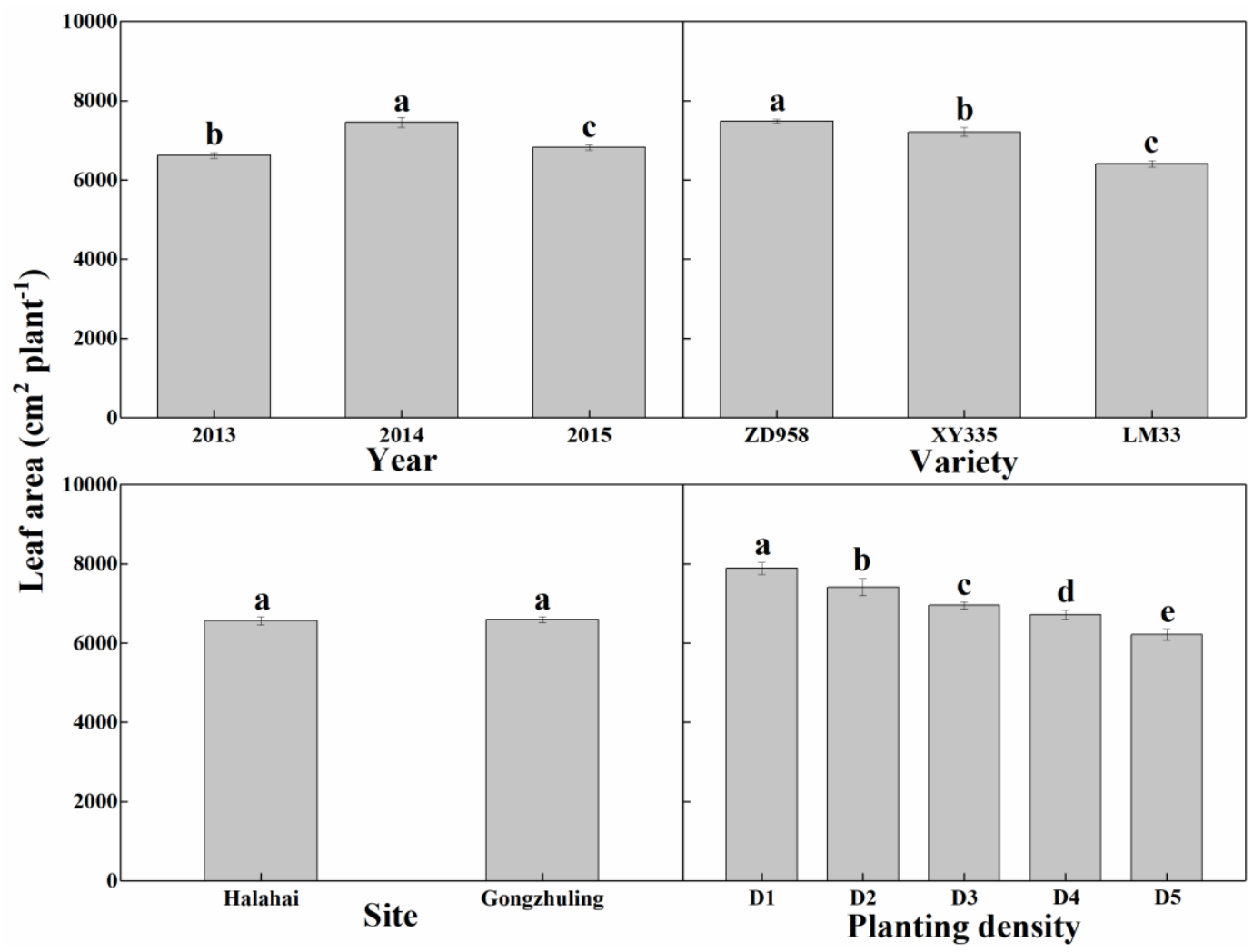

Figure 4. Leaf areas of individual plants. Values are means $\pm S E$. Different lower case letters within panels denote significant pairwise differences between means (LSD test; $P<0.05)$. D1, D2, D3, D4 and D5 indicate planting densities of 45,000, 60,000, 75,000, 90,000 and 105,000 $h a^{-1}$, respectively

The LAI followed the same trend as leaf area/plant by year, hybrid and site (Fig. 5), but this was not the case for planting density: LAI significantly increased with increasing planting density. The LAI under D5 was 83.6\% higher than under D1.

\section{Dry mass accumulation, remobilization and contribution to grain yield}

The dry mass accumulation, remobilization and contribution to grain yield data are listed in Table 3. Among three hybrids, LM33 had significantly lower stalk and leaf dry mass at silking stage than ZD958 and XY335. The stalk dry mass at maturity was not significantly different among hybrids; however, the leaf dry mass of LM33 was strikingly lower than those of ZD958 and XY335. The stalk dry mass remobilization rate and contribution to grain yield were not significantly different among hybrids. The leaves of LM33 leaf had the lowest dry mass remobilization rate and the smallest contribution to grain yield among hybrids. Compared to plants at Halahai, those at 
Gongzhuling had significantly higher stalk and leaf dry mass accumulation rates, dry mass remobilization rates and contributions to grain yield. The dry mass accumulation rates at the silking stage, and the stalk and leaf dry mass accumulation rates at maturity, leaf dry mass remobilization rates, and stalk and leaf contributions to grain yield also increased with increasing planting density. The dry mass of stalks and leaves at silking and maturity, and dry mass remobilization rates and contributions to grain yield all increased over time.

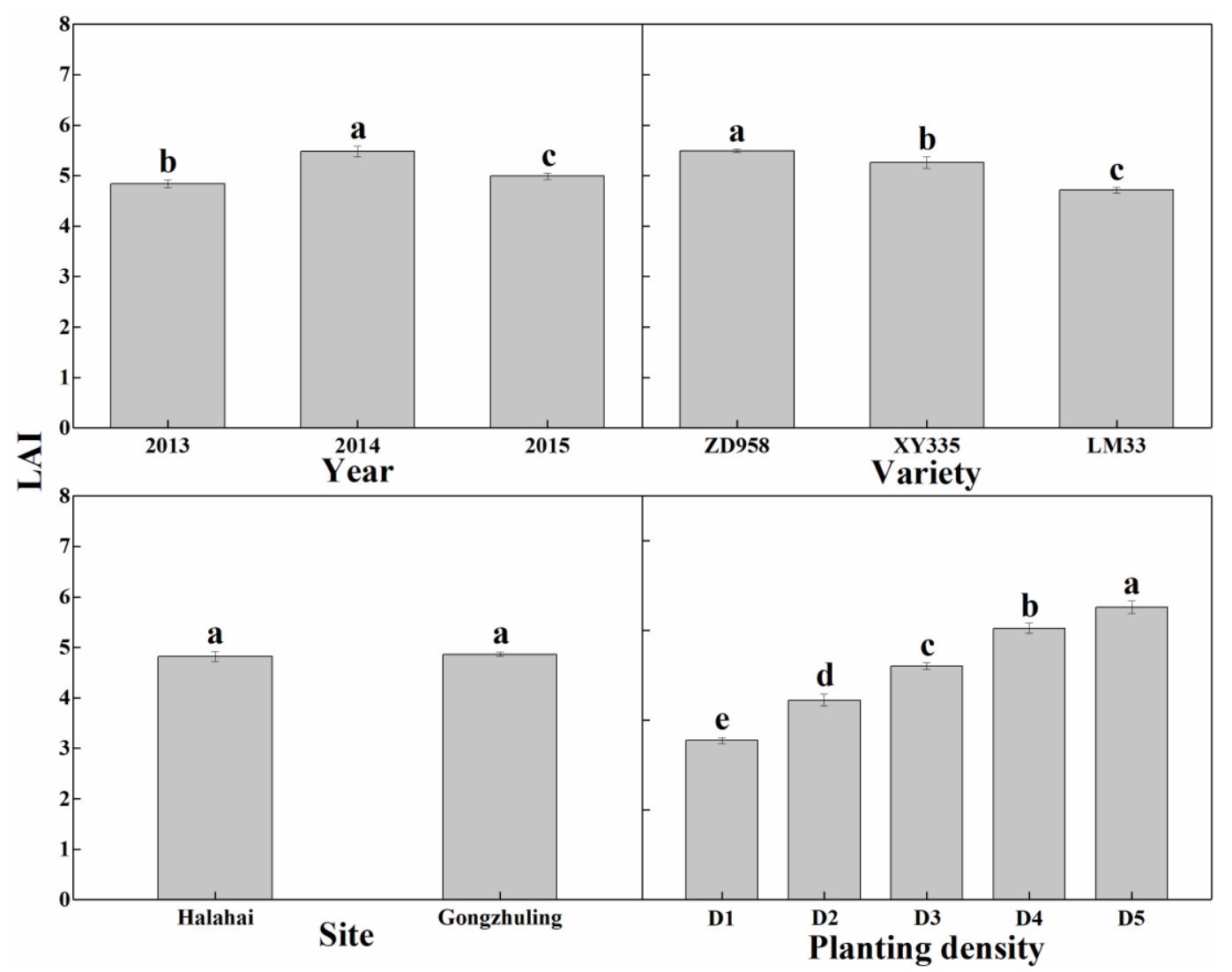

Figure 5. Leaf area of each plant (LAI). Bars indicate standard error. Different lower case letters within panels identify significant pairwise differences between means (LSD test; $P<$ 0.05). D1, D2, D3, D4 and D5 indicate planting densities of 45,000, 60,000, 75,000, 90,000 and $105,000 \mathrm{ha}^{-1}$, respectively

\section{Nitrogen uptake and utilization}

The total $\mathrm{N}$ uptake (TNU) and utilization data are listed in Table 4. LM33 had the highest TNU and $\mathrm{N}$ uptake of $100 \mathrm{~kg}$ grain among the three hybrids; the respective values for LM33 were $10.6 \%$ and $10.1 \%$ higher than those of ZD958. However, the average NPFP of LM33 was the lowest among hybrids (11.8\% lower than the values for ZD958 and XY335). The order of NHI values for the hybrids was as follows: XY335 > LM33 > ZD958. The TNU and NHI values for Halahai were $11.8 \%$ and $1.5 \%$ higher, respectively, than those for Gongzhuling. The NPFP and N uptake of $100 \mathrm{~kg}$ grain were not significantly different between sites. Increased planting density increased the TNU and $\mathrm{N}$ uptake of $100 \mathrm{~kg}$ grain, but decreased NPFP and NHI. The TNU and N uptake of $100 \mathrm{~kg}$ grain of D5 were $15.5 \%$ and $8.5 \%$ higher, respectively, than those of 
D1, but NPFP and NHI under D5 were 7.9\% and 5.3\% lower, respectively, than under D1. Among the three experimental years, the TNU and N uptake of $100 \mathrm{~kg}$ grain were lowest in 2014, but NPFP and NHI highest in that year. The TNU and N uptake of $100 \mathrm{~kg}$ grain values were highest in 2015, but the NPFP and NHI were lowest.

TNU, NFPN, N uptake of $100 \mathrm{~kg}$ grain, and NHI varied significantly among the hybrids (analysis of variance [ANOVA]; $P<0.05$ ). TNU, NFPN and NHI differed significantly between the two experimental sites. TNU, N uptake of $100 \mathrm{~kg}$ grain, and NHI varied significantly by planting density and year.

Table 3. Dry mass (DM) accumulation, remobilization and contribution to grain yield by hybrid, site, year and planting density

\begin{tabular}{|c|c|c|c|c|c|c|c|c|}
\hline \multirow[t]{2}{*}{ Treatments } & \multicolumn{2}{|c|}{$\begin{array}{l}\text { DM at silking } \\
\left(\mathrm{kg} \mathrm{ha}^{-1}\right)\end{array}$} & \multicolumn{2}{|c|}{$\begin{array}{c}\text { DM at maturity } \\
\left(\mathrm{kg} \mathrm{ha}^{-1}\right)\end{array}$} & \multicolumn{2}{|c|}{$\begin{array}{c}\text { DM remobilization } \\
\text { rate }(\%)\end{array}$} & \multicolumn{2}{|c|}{$\begin{array}{l}\text { Contribution to } \\
\text { grain yield (\%) }\end{array}$} \\
\hline & Stalk & Leaf & Stalk & Leaf & Stalk & Leaf & Stalk & Leaf \\
\hline \multicolumn{9}{|l|}{ Hybrids (H) } \\
\hline ZD958 & $6257 \mathrm{a}$ & $3179 \mathrm{a}$ & $5562 \mathrm{a}$ & $2347 \mathrm{a}$ & $11.1 \mathrm{a}$ & $26.2 \mathrm{ab}$ & $7.7 \mathrm{a}$ & $9.2 \mathrm{a}$ \\
\hline XY335 & $6349 \mathrm{a}$ & 3189 a & $5542 \mathrm{a}$ & $2292 b$ & $12.7 \mathrm{a}$ & $28.1 \mathrm{a}$ & $8.2 \mathrm{a}$ & $9.2 \mathrm{a}$ \\
\hline LM33 & $6111 b$ & $2989 \mathrm{~b}$ & 5404 a & $2282 \mathrm{~b}$ & $11.6 \mathrm{a}$ & $23.7 \mathrm{~b}$ & $7.7 \mathrm{a}$ & $7.7 \mathrm{~b}$ \\
\hline \multicolumn{9}{|l|}{ Site (S) } \\
\hline Halahai & $5950 \mathrm{~b}$ & $3044 \mathrm{~b}$ & $5304 \mathrm{~b}$ & $2300 \mathrm{a}$ & $10.9 \mathrm{~b}$ & $24.5 \mathrm{~b}$ & $6.6 \mathrm{~b}$ & $7.6 \mathrm{~b}$ \\
\hline Gongzhuling & $6672 \mathrm{a}$ & $3231 \mathrm{a}$ & $5801 \mathrm{a}$ & $2317 \mathrm{a}$ & $13.1 \mathrm{a}$ & $28.3 \mathrm{a}$ & $10.1 \mathrm{a}$ & $10.6 \mathrm{a}$ \\
\hline \multicolumn{9}{|l|}{ Density (D) } \\
\hline D1 & $5301 \mathrm{e}$ & $2447 \mathrm{e}$ & 4679 e & $2055 \mathrm{e}$ & $11.7 \mathrm{ab}$ & $15.9 \mathrm{~d}$ & $7.2 \mathrm{~b}$ & $4.5 \mathrm{~d}$ \\
\hline D2 & $5842 \mathrm{~d}$ & $2804 \mathrm{~d}$ & $5104 \mathrm{~d}$ & $2187 \mathrm{~d}$ & $12.6 \mathrm{a}$ & $21.9 \mathrm{c}$ & $7.9 \mathrm{~b}$ & $6.6 \mathrm{c}$ \\
\hline D3 & $6378 c$ & $3143 \mathrm{c}$ & $5633 \mathrm{c}$ & $2324 \mathrm{c}$ & $11.7 \mathrm{ab}$ & $26.1 \mathrm{~b}$ & $7.6 \mathrm{~b}$ & $8.3 \mathrm{~b}$ \\
\hline D4 & $6699 \mathrm{~b}$ & $3536 \mathrm{~b}$ & $5960 \mathrm{~b}$ & $2434 b$ & $11.0 \mathrm{~b}$ & $31.1 \mathrm{a}$ & $7.7 \mathrm{~b}$ & $11.4 \mathrm{a}$ \\
\hline D5 & $6976 \mathrm{a}$ & $3665 \mathrm{a}$ & $6139 a$ & $2533 \mathrm{a}$ & $12.0 \mathrm{ab}$ & $30.8 \mathrm{a}$ & $9.2 \mathrm{a}$ & $12.4 \mathrm{a}$ \\
\hline \multicolumn{9}{|l|}{ Year $(Y)$} \\
\hline 2013 & $5965 \mathrm{c}$ & $2688 \mathrm{c}$ & $5376 \mathrm{~b}$ & $2259 \mathrm{a}$ & $9.8 \mathrm{~b}$ & $16.0 \mathrm{~b}$ & $5.9 \mathrm{~b}$ & $4.3 \mathrm{c}$ \\
\hline 2014 & $6156 b$ & $3164 \mathrm{~b}$ & $5478 \mathrm{ab}$ & $2324 \mathrm{a}$ & $11.0 \mathrm{ab}$ & $26.6 \mathrm{a}$ & $6.7 \mathrm{~b}$ & $8.4 \mathrm{~b}$ \\
\hline 2015 & $6460 \mathrm{a}$ & $3289 \mathrm{a}$ & $5591 \mathrm{a}$ & $2314 \mathrm{a}$ & $13.5 \mathrm{a}$ & $29.6 \mathrm{a}$ & $10.5 \mathrm{a}$ & $11.8 \mathrm{a}$ \\
\hline \multicolumn{9}{|l|}{ Source of variation } \\
\hline $\mathbf{H}$ & $* *$ & $* *$ & $* *$ & $*$ & NS & $* *$ & NS & $* *$ \\
\hline $\mathbf{S}$ & $* *$ & NS & $* *$ & NS & NS & NS & $* *$ & $* *$ \\
\hline D & $* *$ & $* *$ & $* *$ & $* *$ & NS & $* *$ & NS & $* *$ \\
\hline $\mathbf{Y}$ & $* *$ & $* *$ & $* *$ & NS & $*$ & $* *$ & $* *$ & $* *$ \\
\hline $\mathbf{H} \times \mathbf{S}$ & $* *$ & $* *$ & $* *$ & NS & NS & $* *$ & NS & $* *$ \\
\hline $\mathbf{H} \times \mathbf{D}$ & $*$ & NS & NS & NS & NS & NS & NS & NS \\
\hline $\mathbf{H} \times \mathbf{Y}$ & $* *$ & $* *$ & $* *$ & $* *$ & NS & NS & NS & NS \\
\hline $\mathbf{S} \times \mathbf{D}$ & $* *$ & NS & $*$ & NS & NS & NS & NS & NS \\
\hline $\mathbf{S} \times \mathbf{Y}$ & NS & $* *$ & NS & $*$ & NS & $*$ & $* *$ & $* *$ \\
\hline $\mathbf{D} \times \mathbf{Y}$ & NS & $* *$ & NS & $* *$ & NS & $* *$ & NS & $* *$ \\
\hline $\mathbf{H} \times \mathbf{S} \times \mathbf{D}$ & NS & NS & NS & NS & NS & NS & NS & NS \\
\hline $\mathbf{H} \times \mathbf{S} \times \mathbf{Y}$ & NS & NS & $* *$ & NS & $* *$ & NS & $* *$ & NS \\
\hline $\mathbf{H} \times \mathbf{D} \times \mathbf{Y}$ & $*$ & NS & NS & NS & NS & NS & NS & NS \\
\hline $\mathbf{S} \times \mathbf{D} \times \mathbf{Y}$ & NS & NS & NS & NS & NS & NS & NS & NS \\
\hline $\mathbf{H} \times \mathbf{S} \times \mathbf{D} \times \mathbf{Y}$ & $* *$ & NS & NS & NS & NS & NS & NS & NS \\
\hline
\end{tabular}

Different lower case letters within columns denote significant pairwise differences between means (LSD test; $\mathrm{P}<0.05)$. * $\mathrm{P}<0.05$. **, $\mathrm{P}<0.01$. NS, no significant difference $(\mathrm{P}>0.05)$. D1, D2, D3, D4 and D5 indicate planting densities of 45,000, 60,000, 75,000, 90,000 and 105,000 ha ${ }^{-1}$, respectively 
Table 4. Total nitrogen uptake (TNU), nitrogen partial factor productivity (NPFP), nitrogen uptake of $100 \mathrm{~kg}$ grain and nitrogen harvest index (NHI) by hybrid, site, year and planting density

\begin{tabular}{|c|c|c|c|c|}
\hline Treatments & TNU $\left(\mathrm{kg} \mathrm{ha}^{-1}\right)$ & NPFP $\left(\mathrm{kg} \mathrm{kg}^{-1}\right)$ & $\begin{array}{c}\mathrm{N} \text { uptake of } 100 \mathrm{~kg} \text { grain } \\
(\mathrm{kg})\end{array}$ & NHI \\
\hline \multicolumn{5}{|l|}{ Hybrids (H) } \\
\hline ZD958 & $168.0 \mathrm{c}$ & $54.2 \mathrm{a}$ & $1.88 \mathrm{~b}$ & $0.644 \mathrm{c}$ \\
\hline XY335 & $179.6 \mathrm{~b}$ & $54.9 \mathrm{a}$ & $1.86 \mathrm{~b}$ & $0.684 \mathrm{a}$ \\
\hline LM33 & $185.8 \mathrm{a}$ & $48.8 \mathrm{~b}$ & $2.07 \mathrm{a}$ & $0.672 \mathrm{~b}$ \\
\hline \multicolumn{5}{|l|}{ Site (S) } \\
\hline Halahai & $185.7 \mathrm{a}$ & $52.9 \mathrm{a}$ & $1.91 \mathrm{a}$ & $0.671 \mathrm{a}$ \\
\hline Gongzhuling & $166.1 \mathrm{~b}$ & $52.3 \mathrm{a}$ & $1.95 \mathrm{a}$ & $0.661 \mathrm{~b}$ \\
\hline \multicolumn{5}{|l|}{ Density (S) } \\
\hline D1 & $159.4 \mathrm{c}$ & $54.2 \mathrm{a}$ & $1.88 \mathrm{c}$ & $0.678 \mathrm{a}$ \\
\hline D2 & $172.9 \mathrm{~b}$ & $54.2 \mathrm{a}$ & $1.88 \mathrm{c}$ & $0.680 \mathrm{a}$ \\
\hline D3 & $184.7 \mathrm{a}$ & $53.7 \mathrm{a}$ & $1.90 \mathrm{c}$ & $0.675 \mathrm{a}$ \\
\hline D4 & $188.0 \mathrm{a}$ & $51.4 \mathrm{~b}$ & $1.98 \mathrm{~b}$ & $0.660 \mathrm{~b}$ \\
\hline D5 & $184.1 \mathrm{a}$ & $49.9 \mathrm{~b}$ & $2.04 \mathrm{a}$ & $0.642 \mathrm{c}$ \\
\hline \multicolumn{5}{|l|}{ Year $(\mathbf{Y})$} \\
\hline 2013 & $179.8 \mathrm{a}$ & $55.3 \mathrm{~b}$ & $1.82 \mathrm{~b}$ & $0.654 \mathrm{~b}$ \\
\hline 2014 & $173.5 \mathrm{~b}$ & $58.4 \mathrm{a}$ & $1.73 \mathrm{c}$ & $0.701 \mathrm{a}$ \\
\hline 2015 & $181.1 \mathrm{a}$ & $45.6 \mathrm{c}$ & $2.20 \mathrm{a}$ & $0.640 \mathrm{c}$ \\
\hline \multicolumn{5}{|l|}{ Source of variation } \\
\hline $\mathbf{H}$ & $* *$ & $*$ & $* *$ & $* *$ \\
\hline $\mathbf{S}$ & $* *$ & $* *$ & NS & $* *$ \\
\hline D & $* *$ & NS & $* *$ & $* *$ \\
\hline $\mathbf{Y}$ & $* *$ & NS & $* *$ & $* *$ \\
\hline $\mathbf{H} \times \mathbf{S}$ & NS & NS & $* *$ & $* *$ \\
\hline $\mathbf{H} \times \mathbf{D}$ & NS & NS & NS & NS \\
\hline $\mathbf{H} \times \mathbf{Y}$ & $* *$ & NS & $* *$ & $* *$ \\
\hline $\mathbf{S} \times \mathbf{D}$ & NS & NS & NS & NS \\
\hline $\mathbf{S} \times \mathbf{Y}$ & $* *$ & $* *$ & $* *$ & $* *$ \\
\hline $\mathbf{D} \times \mathbf{Y}$ & NS & NS & * & $* *$ \\
\hline $\mathbf{H} \times \mathbf{S} \times \mathbf{D}$ & NS & NS & NS & NS \\
\hline $\mathbf{H} \times \mathbf{S} \times \mathbf{Y}$ & $* *$ & $* *$ & $* *$ & NS \\
\hline $\mathbf{H} \times \mathbf{D} \times \mathbf{Y}$ & NS & NS & NS & NS \\
\hline $\mathbf{S} \times \mathbf{D} \times \mathbf{Y}$ & NS & NS & NS & $*$ \\
\hline $\mathbf{H} \times \mathbf{S} \times \mathbf{D} \times \mathbf{Y}$ & NS & NS & NS & NS \\
\hline
\end{tabular}

Different lower case letters within columns denote significant pairwise differences between means (LSD test; $\mathrm{P}<0.05)$. *, $\mathrm{P}<0.05$. **, $\mathrm{P}<0.01$. NS, no significant difference $(\mathrm{P}>0.05)$. D1, D2, D3, D4 and D5 indicate planting densities of 45,000,60,000, 75,000, 90,000 and 105,000 $\mathrm{ha}^{-1}$, respectively

\section{Nitrogen accumulation, remobilization and contribution to grain yield}

Although ZD958 had the highest stalk TNU at silking and maturity, its stalk N remobilization rate was lowest among hybrids (Table 5). The leaf TNU values at silking and maturity, and the $\mathrm{N}$ remobilization rate of ZD958, were not the highest among hybrids. ZD958 had the highest stalk and leaf contributions to grain N; they were $11.9 \%$ and $14.3 \%$ higher, respectively, than the lowest values among hybrids. The stalks at Gongzhuling had higher TNU values at silking, and higher $\mathrm{N}$ remobilization rates and 
contributions to grain $\mathrm{N}$ than stalks at Halahai. However, plants at Halahai had higher leaf TNU values at silking, $\mathrm{N}$ remobilization rates and contributions to grain N. Stalk and leaf TNU at maturity did not differ significantly between sites. Increases in planting density significantly increased stalk and leaf TNU values at silking and maturity, as well as leaf $\mathrm{N}$ remobilization rates and contributions to grain $\mathrm{N}$. However, the $\mathrm{N}$ remobilization rate of the stalk was significantly decreased by increased planting density. The TNU, $\mathrm{N}$ remobilization rate, and contributions of stalk and leaf differed significantly among years.

Table 5. Total nitrogen uptake (TNU), nitrogen remobilization rate and contribution to grain nitrogen uptake by hybrid, site, year and planting density

\begin{tabular}{|c|c|c|c|c|c|c|c|c|}
\hline \multirow[t]{2}{*}{ Treatments } & \multicolumn{2}{|c|}{$\begin{array}{l}\text { TNU at silking } \\
\quad\left(\mathrm{kg} \mathrm{ha}^{-1}\right)\end{array}$} & \multicolumn{2}{|c|}{$\begin{array}{l}\text { TNU at maturity } \\
\quad\left(\mathrm{kg} \mathrm{ha}^{-1}\right)\end{array}$} & \multicolumn{2}{|c|}{$\begin{array}{l}\mathrm{N} \text { remobilization } \\
\text { rate }(\%)\end{array}$} & \multicolumn{2}{|c|}{$\begin{array}{c}\text { Contribution to } \\
\text { grain } \mathbf{N} \\
(\%)\end{array}$} \\
\hline & Stalk & Leaf & Stalk & Leaf & Stalk & Leaf & Stalk & Leaf \\
\hline \multicolumn{9}{|l|}{ Hybrids (H) } \\
\hline ZD958 & $62.9 \mathrm{a}$ & $72.4 \mathrm{~b}$ & $28.9 \mathrm{a}$ & $26.9 \mathrm{~b}$ & $54.1 \mathrm{~b}$ & $62.8 \mathrm{~b}$ & $31.1 \mathrm{a}$ & $41.6 \mathrm{a}$ \\
\hline XY335 & $58.1 \mathrm{c}$ & $75.9 \mathrm{a}$ & $23.9 \mathrm{~b}$ & $25.8 \mathrm{c}$ & $58.8 \mathrm{a}$ & $66.0 \mathrm{a}$ & $27.8 \mathrm{~b}$ & $40.8 \mathrm{a}$ \\
\hline LM33 & $59.4 \mathrm{~b}$ & $75.0 \mathrm{ab}$ & $24.6 \mathrm{~b}$ & $29.5 \mathrm{a}$ & $58.6 \mathrm{a}$ & $60.7 \mathrm{~b}$ & $27.8 \mathrm{~b}$ & $36.4 \mathrm{~b}$ \\
\hline Site (S) & & & & & & & & \\
\hline Halahai & $59.5 \mathrm{~b}$ & $81.6 \mathrm{a}$ & $26.5 \mathrm{a}$ & $27.6 \mathrm{a}$ & $55.5 \mathrm{~b}$ & $66.2 \mathrm{a}$ & $26.4 \mathrm{~b}$ & $43.3 \mathrm{a}$ \\
\hline Gongzhuling & $61.1 \mathrm{a}$ & $63.6 \mathrm{~b}$ & $23.6 \mathrm{a}$ & $27.0 \mathrm{a}$ & $61.4 \mathrm{a}$ & $57.5 \mathrm{~b}$ & $34.0 \mathrm{a}$ & $33.2 \mathrm{~b}$ \\
\hline \multicolumn{9}{|l|}{ Density (D) } \\
\hline D1 & $53.2 \mathrm{c}$ & $60.0 \mathrm{~d}$ & $21.6 \mathrm{~d}$ & $24.8 \mathrm{e}$ & $59.4 \mathrm{a}$ & $58.7 \mathrm{~d}$ & $29.2 \mathrm{a}$ & $32.5 \mathrm{e}$ \\
\hline D2 & $57.9 \mathrm{~b}$ & $68.2 \mathrm{c}$ & $23.1 \mathrm{c}$ & $26.3 \mathrm{~d}$ & $60.0 \mathrm{a}$ & $61.4 \mathrm{c}$ & $29.5 \mathrm{a}$ & $35.5 \mathrm{~d}$ \\
\hline D3 & $61.9 \mathrm{a}$ & $75.1 \mathrm{~b}$ & $25.6 \mathrm{~b}$ & $27.4 \mathrm{c}$ & $58.8 \mathrm{a}$ & $63.5 \mathrm{~b}$ & $29.1 \mathrm{a}$ & $38.2 \mathrm{c}$ \\
\hline D4 & $63.0 \mathrm{a}$ & $83.4 \mathrm{a}$ & $28.1 \mathrm{a}$ & $28.5 \mathrm{~b}$ & $55.5 \mathrm{~b}$ & $65.9 \mathrm{a}$ & $28.8 \mathrm{a}$ & $44.2 \mathrm{~b}$ \\
\hline D5 & $64.6 \mathrm{a}$ & $85.5 \mathrm{a}$ & $28.2 \mathrm{a}$ & $29.8 \mathrm{a}$ & $56.5 \mathrm{~b}$ & $65.1 \mathrm{a}$ & $30.8 \mathrm{a}$ & $47.1 \mathrm{a}$ \\
\hline \multicolumn{9}{|l|}{ Year $(\mathbf{Y})$} \\
\hline 2013 & $59.6 \mathrm{~b}$ & $81.6 \mathrm{a}$ & $28.2 \mathrm{a}$ & $27.5 \mathrm{~b}$ & $52.8 \mathrm{~b}$ & $66.3 \mathrm{a}$ & $26.8 \mathrm{~b}$ & $46.1 \mathrm{a}$ \\
\hline 2014 & $62.6 \mathrm{a}$ & $70.3 \mathrm{c}$ & $22.2 \mathrm{c}$ & $24.4 \mathrm{c}$ & $64.6 \mathrm{a}$ & $65.3 \mathrm{a}$ & $33.2 \mathrm{a}$ & $37.7 \mathrm{~b}$ \\
\hline 2015 & $58.8 \mathrm{~b}$ & $74.9 \mathrm{~b}$ & $27.0 \mathrm{~b}$ & $30.2 \mathrm{a}$ & $54.1 \mathrm{~b}$ & $59.7 \mathrm{~b}$ & $27.4 \mathrm{~b}$ & $38.4 \mathrm{~b}$ \\
\hline \multicolumn{9}{|l|}{ Source of variation } \\
\hline $\mathbf{V}$ & $* *$ & $* *$ & $* *$ & $* *$ & $* *$ & $* *$ & $* *$ & $* *$ \\
\hline $\mathbf{S}$ & $* *$ & $* *$ & $* *$ & * & ** & $* *$ & ** & $* *$ \\
\hline D & $* *$ & $* *$ & $* *$ & $* *$ & $* *$ & $* *$ & $*$ & $* *$ \\
\hline $\mathbf{Y}$ & $* *$ & $* *$ & $* *$ & $* *$ & $* *$ & $* *$ & $* *$ & $* *$ \\
\hline $\mathbf{H} \times \mathbf{S}$ & $*$ & $* *$ & $*$ & $* *$ & NS & $* *$ & $* *$ & $* *$ \\
\hline $\mathbf{H} \times \mathbf{D}$ & NS & NS & $* *$ & NS & NS & NS & NS & NS \\
\hline $\mathbf{H} \times \mathbf{Y}$ & $* *$ & $* *$ & $* *$ & $* *$ & $* *$ & $* *$ & $* *$ & $* *$ \\
\hline $\mathbf{S} \times \mathbf{D}$ & $*$ & $* *$ & NS & $* *$ & NS & $*$ & * & $* *$ \\
\hline $\mathbf{S} \times \mathbf{Y}$ & $* *$ & $* *$ & NS & $* *$ & NS & $* *$ & $*$ & $*$ \\
\hline $\mathbf{D} \times \mathbf{Y}$ & $* *$ & $*$ & $* *$ & $* *$ & NS & $*$ & NS & NS \\
\hline $\mathbf{H} \times \mathbf{S} \times \mathbf{D}$ & NS & NS & NS & NS & NS & NS & NS & NS \\
\hline $\mathbf{H} \times \mathbf{S} \times \mathbf{Y}$ & NS & NS & $* *$ & $* *$ & $* *$ & $* *$ & $* *$ & $* *$ \\
\hline $\mathbf{H} \times \mathbf{D} \times \mathbf{Y}$ & NS & NS & $*$ & NS & NS & NS & NS & NS \\
\hline $\mathbf{S} \times \mathbf{D} \times \mathbf{Y}$ & NS & $* *$ & NS & NS & NS & $* *$ & NS & $* *$ \\
\hline $\mathbf{H} \times \mathbf{S} \times \mathbf{D} \times \mathbf{Y}$ & $\mathrm{NS}$ & NS & NS & NS & NS & NS & NS & NS \\
\hline
\end{tabular}

Different lower case letters within columns denote significant pairwise differences between means (LSD test; $\mathrm{P}<0.05)$. *, P < 0.05. **, P < 0.01. NS, no significant difference $(\mathrm{P}>0.05)$. D1, D2, D3, D4 and D5 indicate planting densities of 45,000,60,000, 75,000, 90,000 and 105,000 $\mathrm{ha}^{-1}$, respectively 
ANOVA showed that hybrid, site, planting density and year all had significant effects on the TNU, N remobilization rate, and stalk and leaf contributions to grain $\mathrm{N}$.

\section{Discussion}

\section{Grain yield}

Improvements in field management practice have the potential to increase the grain yield of modern maize hybrids by 50\% (Xu et al., 2017). The choice of an optimum planting density is an element of best practice that can be readily implemented by working farmers. Across China, maize planting density ranges from $49,850 \mathrm{ha}^{-1}$ on the Huaihai Plain to 65,180 ha $\mathrm{ha}^{-1}$ in Northwest China (Meng et al., 2013; Li et al., 2016). However, in other regions, maize planting density ranges from 79,072 to $105,000 \mathrm{ha}^{-1}$ (Kratochvil and Taylor, 2005; Robles et al., 2012; Novacek et al., 2013). Optimum planting density is an important element of efforts to maximize maize grain yield. However, optimum planting density is influenced by hybrid and environmental conditions. It is therefore difficult to identify an optimum planting density before planting (Cox and Cherney, 2012; Reeves and Cox, 2013). We found that grain yields varied significantly by year, hybrid and site (Fig. 3). Crop production depends on the yields of whole populations, rather than individual plants; hence, selection of an appropriate planting density is vital to realize high yields. The lowest and highest planting densities selected for the three hybrids in this study were $45,000 \mathrm{ha}^{-1}$ and $105,000 \mathrm{ha}^{-1}$, respectively. Grain yield data indicated that $75,000 \mathrm{ha}^{-1}$ was an appropriate planting density overall. However, the most appropriate planting density for each experiment varied among years, hybrids and sites (Table 2), indicating that planting density is not a fixed variable in maize cultivation. We found that the average optimum planting densities for hybrids ZD958, XY335 and LM33 were 78.3, 77.0 and $84.1 \times 10^{3} \mathrm{ha}^{-1}$, respectively. Xu et al. (2017) reported that the optimum planting density of ZD958 at Gongzhuling was $75.0 \times 10^{3}$ plants $\mathrm{ha}^{-1}$, similar to our findings. Excessively high planting densities led to yield losses of all three hybrids in our study. Also, Amanullah et al. (2007) reported that increased maize planting density decreased the kernel number, ear size and 1,000 kernel weights, leading to an overall reduction in yield.

\section{Leaf development}

The leaf is the major photosynthetic organ of maize, and the photosynthetic capacity of this crop depends largely on leaf canopy structure and physiological characteristics. Ning et al. (2013) and Ci et al. (2012) showed that improvements in maize yield are closely related to the leaf stay-green characteristics of modern hybrids. Larger leaf area and longer leaf area duration are closely related to improve maize grain yields (Francone et al., 2014). We found significant differences in leaf area per plant (Fig. 4) and LAI (Fig. 5) among the three hybrids tested. Increasing planting density affected both the leaf area of each plant and the LAI: leaf area per plant decreased with increased planting density, but LAI increased. The negative effect of increased density on the leaf area of individual plants can be offset by concomitant increases in the population leaf area. 


\section{Dry mass and nitrogen remobilization}

Dry mass accumulation reflects the plant growth and development status. High dry mass is fundamental to high grain yield. All dry mass gains after silking contribute to grain yield, and most of the grain yield is a product of the dry mass accumulated after the silking stage (Ning et al., 2013). In this study, increased planting density significantly increased the stalk and leaf dry mass at silking and maturity, and also increased the proportional contribution to grain yield (Table 2). Dordas and Sioulas (2009) reported that grain yield was mainly determined by the accumulation of dry mass. Xu et al. (2017) found that the harvest index decreased with increased planting density. However, dry mass accumulation contributes more to grain yield than the harvest index (Peng et al., 2004).

Most leaf $\mathrm{N}$ is mobilized and transferred to grain (Hirel et al., 2007) during the grain filling stage. Chen et al. (2014) worked with hybrid XY335 and reported that approximately $70 \%$ of the leaf $\mathrm{N}$ accumulated at the silking stage was transferred to the grain. We also used this hybrid in our trials and obtained a similar leaf $\mathrm{N}$ remobilization rate $(66.0 \%)$ (Table 5). Improvements in breeding technology have significantly increased the uptake of $\mathrm{N}$, and new maize hybrids have a higher $\mathrm{N}$ use efficiency than older hybrids (Lee and Tollenaar, 2007; Worku et al., 2007; Haegele et al., 2013). In this study, there were significant differences in the TNU, NPFP, N uptake of $100 \mathrm{~kg}$ grain and NHI values among the three hybrids (Table 4), thereby demonstrating the existence of inter-varietal differences in $\mathrm{N}$ uptake and utilization. We supplied $\mathrm{N}$ at a constant rate to the three hybrids included in this study. $\mathrm{N}$ is an essential nutrient for maize growth and development, and optimum $\mathrm{N}$ rate guidelines should be developed to take account of the interactions among climate, site, hybrid and planting density.

\section{Conclusion}

We demonstrated significant effects of maize hybrid and planting density on grain yield, leaf growth and development, dry mass accumulation and remobilization, as well as $\mathrm{N}$ uptake and utilization. The three hybrids had similar grain yield trends, but the optimum planting density varied by hybrid. The optimum planting densities for enhanced grain yield in ZD958, XY335 and LM33 were 74.0-81.4, 74.3-79.1, and 78.6-89.7 $\times 10^{3} \mathrm{ha}^{-1}$, respectively, across years and sites, showing that LM33 had the highest density tolerance. The increase in planting density had significant inhibitory effects on the leaf growth and development of individual plants, but this was offset by positive effects at the population level. Increased planting density improved dry mass and TNU, and promoted dry mass and $\mathrm{N}$ transfer from stalks and leaves to grain, thereby enhancing yield. In order to get a higher grain yield, modern maize hybrids should be combined with appropriate plant densities and suitable growing environments.

Acknowledgments. This work was supported by the National Key Research and Development Program of China (No. 2017YFD0300602) and the Science and Technology Development Planning Project of Jilin Province, China (No. 20180201077NY). 


\section{REFERENCES}

[1] Amanullah, M. J. H., Nawab, K., Ali, A. (2007): Response of specific leaf area (SLA), leaf area index (LAI) and leaf area ratio (LAR) of maize (Zea mays L.) to plant density rate and timing of nitrogen application. - World Applied Sciences Journal 2: 235-243.

[2] Bertin, P., Gallais, A. (2000): Genetic variation for nitrogen use efficiency in a set of recombinant maize inbred lines. I. Agrophysiological results. - Maydica 45: 53-66.

[3] Borrell, A. K., Hammer, G. L., Oosterom, E. V. (2001): Stay-green: a consequence of the balance between supply and demand for nitrogen during grain filling. - Annals of Applied Biology 138: 91-95.

[4] Chen, X., Cui, Z., Vitousek, P. M., Cassman, K. G., Matson, P. A., Bai, J., Meng, Q., Hou, P., Yue, S., Römheld, V. (2011): Integrated soil-crop system management for food security. - Proceedings of the National Academy of Sciences of the United States of America 108: 6399-6404.

[5] Chen, F., Fang, Z., Gao, Q., Ye, Y., Jia, L., Yuan, L., Mi, G., Zhang, F. (2013a): Evaluation of the yield and nitrogen use efficiency of the dominant maize hybrids grown in North and Northeast China. - Science China-Life Sciences 56: 552-560.

[6] Chen, X., Chen, F., Chen, Y., Gao, Q., Yang, X., Yuan, L., Zhang, F., Mi, G. (2013b): Modern maize hybrids in Northeast China exhibit increased yield potential and resource use efficiency despite the adverse climate change. - Global Change Biology 19: 923-936.

[7] Chen, Y., Xiao, C., Chen, X., Li, Q., Zhang, J., Chen, F., Yuan, L., Mi, G. (2014): Characterization of the plant traits contributed to high grain yield and high grain nitrogen concentration in maize. - Field Crops Research 159: 1-9.

[8] Chen, Y., Xiao, C., Wu, D., Xia, T., Chen, Q., Chen, F., Yan, L., Mi, G. (2015): Effects of nitrogen application rate on grain yield and grain nitrogen concentration in two maize hybrids with contrasting nitrogen remobilization efficiency. - European Journal of Agronomy 62: 79-89.

[9] Ci, X., Li, M., Xu, J., Lu, Z., Bai, P., Ru, G., Liang, X., Zhang, D., Li, X., Bai, L., Xie, C., Hao, Z., Zhang, S., Dong, S. (2012): Trends of grain yield and plant traits in Chinese maize cultivars from the 1950s to the 2000s. - Euphytica 185: 395-406.

[10] Ciampitti, I. A., Vyn, T. J. (2012): Physiological perspectives of changes over time in maize yield dependency on nitrogen uptake and associated nitrogen efficiencies: A review. - Field Crops Research 133: 48-67.

[11] Coque, M., Gallais, A. (2007): Genetic variation for nitrogen remobilization and postsilking nitrogen uptake in maize recombinant inbred lines: heritabilities and correlations among traits. - Crop Science 47: 1787-1796.

[12] Cox, W. J., Cherney, J. H. (2012): Lack of hybrid, seeding, and nitrogen rate interactions for corn growth and yield. - Agronomy Journal 104: 945-952.

[13] Diós, D., Szenteleki, K., Ferenczy, A. (2009): A climate profile indicator based comparative analysis of climate change scenarios with regard to maize (Zea mays L.) cultures. - Applied Ecology \& Environmental Research 7: 199-214.

[14] Dordas, C. A., Sioulas, C. (2009): Dry matter and nitrogen accumulation, partitioning, and retranslocation in safflower (Carthamus tinctorius L.) as affected by nitrogen fertilization. - Field Crops Research 110: 35-43.

[15] Duvick, D. N. (2005): The contribution of breeding to yield advances in maize (Zea mays L.). - Advances in Agronomy 86: 83-145.

[16] Echarte, L., Rothstein, S., Tollenaar, M. (2008): The response of leaf photosynthesis and dry matter accumulation to nitrogen supply in an older and a newer maize hybrid. - Crop Science 48: 656-665.

[17] Francone, C., Pagani, V., Foi, M., Cappelli, G., Confalonieri, R. (2014): Comparison of leaf area index estimates by ceptometer and Pocket LAI smart app in canopies with different structures. - Field Crops Research 155: 38-41. 
[18] Gallais, A., Coque, M., Quilléré, I. (2006): Modelling post-silking nitrogen fluxes in maize (Zea mays L.) using ${ }^{15} \mathrm{~N}$-labelling field experiments. - New Phytologist 172: 696707.

[19] Grassini, P., Cassman, K. G. (2012): High-yield maize with large net energy yield and small global warming intensity. - Proceeding of the National Academy of Science of the United States of America 109: 1074-1079.

[20] Gu, R., Li, L., Liang, X., Wang, Y., Fan, T., Wang, Y., Wang, J. (2017): The ideal harvest time for seeds of hybrid maize (Zea mays L.) XY335 and ZD958 produced in multiple environments. - Scientific Reports 7: 17537.

[21] Haegele, J. W., Cook, K. A., Nichols, D. M., Below, F. E. (2013): Changes in nitrogen use traits associated with genetic improvement for grain yield of maize hybrids released in different decades. - Crop Science 53: 1-13.

[22] He, P., Zhou, W., Jin, J. (2004): Carbon and nitrogen metabolism related to grain formation in two different senescent types of maize. - Journal of Plant Nutrition 27: 295311.

[23] Hirel, B., Gouis, J. L., Ney, B., Gallais, A. (2007): The challenge of improving nitrogen use efficiency in crop plants: Towards a more central role for genetic variability and quantitative genetics within integrated approaches. - Journal of Experimental Botany 58: 2369-2387.

[24] Hou, W., Khan, M. R., Zhang, J., Lu, J., Ren, T., Cong, R., Li, X. (2019): Nitrogen rate and plant density interaction enhances radiation interception, yield and nitrogen use efficiency of mechanically transplanted rice. - Agriculture, Ecosystems \& Environment 269: 183-192.

[25] Kratochvil, R. J., Taylor, R. W. (2005): Twin-row corn production: An evaluation in the Mid-Atlantic Delmarva Region. - Crop Management 4(1): 1-7.

[26] Lee, E. A., Tollenaar, M. (2007): Physiological basis of successful breeding strategies for maize grain yield. - Crop Science 47: 202-215.

[27] Li, C., Tao, Z., Liu, P., Zhang, J., Zhuang, K., Dong, S., Zhao, M. (2015): Increased grain yield with improved photosynthetic characters in modern maize parental lines. - Journal of Integrative Agriculture 14: 1735-1744.

[28] Li, S., Wang, K., Xie, R., Hou, P., Ming, B., Yang, X., Han, D., Wang, Y. (2016): Implementing higher population and full mechanization technologies to achieve high yield and high efficiency in maize production. - Crops 4: 1-6. (in Chinese with English abstract).

[29] Liu, T., Gu, L., Dong, S., Zhang, J., Liu, P., Zhao, B. (2015): Optimum leaf removal increases canopy apparent photosynthesis: ${ }^{13} \mathrm{C}$-photosynthate distribution and grain yield of maize crops grown at high density. - Field Crops Research 170: 32-39.

[30] Ma, W., Li, J., Ma, L., Wang, F., Sisák, I., Cushman, G., Zhang, F. (2009): Nitrogen flow and use efficiency in production and utilization of wheat, rice, and maize in China. Agricultural Systems 99: 53-63.

[31] Meng, Q., Hou, P., Wu, L., Chen, X., Cui, Z., Zhang, F. (2013): Understanding production potentials and yield gaps in intensive maize production in China. - Field Crops Research 143: 91-97.

[32] National Bureau of Statistics. (2018): China Statistical Yearbook. - China Statistics Press, Beijing (in Chinese with English abstract).

[33] Ning, P., Li, S., Yu, P., Zhang, Y., Li, C. (2013): Post-silking accumulation and partitioning of dry matter, nitrogen, phosphorus and potassium in maize varieties differing in leaf longevity. - Field Crops Research 144: 19-27.

[34] Novacek, M. J., Mason, S. C., Galusha, T. D., Yaseen, M. (2013): Bt transgenes minimally influence maize grain yield and lodging across plant populations. - Maydica 59: 90-95.

[35] Peng, S., Huang, J., Sheehy, J. E., Laza, R. C., Visperas, R. M., Zhong, X., Centeno, G. S., Khush, G. S., Cassman, K. G. (2004): Rice yields decline with higher night 
temperature from global warming. - Proceedings of the National Academy of Sciences of the United States of America 101: 9971-9975.

[36] Pommel, B., Gallais, A., Coque, M., Quillere, I., Hirel, B., Prioul, J. L., Andrieu, B., Floriot, M. (2006): Carbon and nitrogen allocation and grain filling in three maize hybrids differing in leaf senescence. - European Journal of Agronomy 24: 203-211.

[37] Reeves, G. W., Cox, W. J. (2013): Inconsistent responses of corn to seeding rates in fieldscale studies. - Agronomy Journal 105: 693-704.

[38] Robles, M., Ciampitti, I. A., Vyn, T. J. (2012): Responses of maize hybrids to twin-row spatial arrangement at multiple plant densities. - Agronomy Journal 104: 1747-1756.

[39] Srinivasan, V., Kumar, P., Long, S. P. (2017): Decreasing, not increasing, leaf area will raise crop yields under global atmospheric change. - Global Change Biology 23: 16261635.

[40] Sun, M., Huo, Z., Zheng, Y., Dai, X., Feng, S., Mao, X. (2018): Quantifying long-term responses of crop yield and nitrate leaching in an intensive farmland using agro-ecoenvironmental model. - Science of the Total Environment 613-614: 1003-1012.

[41] Tollenaar, M., Ahmadzadeh, A., Lee, E. A. (2004): Physiological basis of heterosis for grain yield in maize. - Crop Science 44: 2086-2094.

[42] Wolf, B. (1982): A comprehensive systems of leaf analysis and its use for diagnosing crop nutrient status. - Communications in Soil Science and Plant Analysis 13: 10351059.

[43] Worku, M., Bänziger, M., Friesen, D., Horst, W. J. (2007): Nitrogen uptake and utilization in contrasting nitrogen efficient tropical maize hybrids. - Crop Science 47: 519-528.

[44] Xu, W., Liu, C., Wang, K., Xie, R., Ming, B., Wang, Y., Zhang, G., Liu, G., Zhao, R., Fan, P., Li, S., Hou, P. (2017): Adjusting maize plant density to different climatic conditions across a large longitudinal distance in China. - Field Crops Research 212: 126-134.

[45] Xue, H., Han, Y., Li, Y., Wang, G., Lu, F., Fan, Z., Du, W., Yang, B., Mao, S. (2015): Spatial distribution of light interception by different plant population densities and its relationship with yield. - Field Crops Research 184: 17-27. 